\title{
Does Environmental Stress Affect Economic Growth: Evidence from the Gulf Cooperation Council countries?
}

Osama Daifalla D. Sweidan ( $D$ osweidan@uaeu.ac.ae)

United Arab Emirates University https://orcid.org/0000-0003-4503-5883

Khadiga Elbargathi

Al-Zaytoonah Private University of Jordan Faculty of Economics and Administration

\section{Research Article}

Keywords: Sustainability economics, Economic growth, $\mathrm{CO} 2$ emissions, Human well-being, Panel cointegration analysis, The GCC countries

Posted Date: March 10th, 2021

DOl: https://doi.org/10.21203/rs.3.rs-263018/v1

License: (c) (i) This work is licensed under a Creative Commons Attribution 4.0 International License.

Read Full License

Version of Record: A version of this preprint was published at Clean Technologies and Environmental Policy on July 25th, 2021. See the published version at https://doi.org/10.1007/s10098-021-02169-x. 


\title{
Does environmental stress affect economic growth: Evidence from the Gulf Cooperation Council countries?
}

\author{
Osama D. Sweidan, Ph.D. (Corresponding author) \\ Department of Innovation in \\ Government and Society \\ United Arab Emirates University \\ Al-Ain, P.O. Box 15551, UAE \\ Tel: +97137135297 \\ e-mail: osweidan@uaeu.ac.ae \\ ORCID: 0000-0003-4503-5883
}

\section{Khadiga Elbargathi, Ph.D.}

Assistant Professor of Economics

Department of Economic Sciences

Al-Zaytoonah University of Jordan

Amman, Jordan

k.elbargathi@zuj.edu.jo

ORCID: 0000-0002-8324-2026

\begin{abstract}
This paper empirically investigates the influence of environmental stress on economic growth in the GCC countries during (1995-2016). We use a panel cointegration analysis and compute an autoregressive distributed lag model. Our paper is motivated by the high $\mathrm{CO}_{2}$ emissions per capita and environmental stress in these countries relative to other countries. We assume that the income per capita is a function of the natural resource's rents and environmental stress. Our findings show that environmental stress has a positive and significant effect on economic growth, mainly in the long run. Further, the natural resources' rents have a significant positive effect in the short run, while the long run impact is negative. Our paper's policy implication states that economic policymakers should monitor and evaluate future environmental stress outcomes in these countries. There is no guarantee that the positive influence prevails. Therefore, they should diversify their economies and energy resources.
\end{abstract}

Jel Classification: Q51, Q56.

Keywords: Sustainability economics; Economic growth; $\mathrm{CO}_{2}$ emissions; Human wellbeing, Panel cointegration analysis; The GCC countries. 


\section{Declarations}

Funding: There is no funding for this work.

Conflicts of interest/Competing interests: The authors declare that they have no conflict of interest.

Availability of data and material: All the data are available Mendeley data repository.

Code availability: STAT 16 Software

Authors' contributions: Both authors worked equally on the paper. 


\section{Introduction}

Sustainable economics is an old economic thought and has been attracting the attention of many economists. Its core idea concentrates on allocating the limited resources to satisfy the unlimited needs and desires or adjusting the lifestyle to comply with the finite resources (Sweidan, 2016). Nowadays, economic sustainability is growing very fast because of global environmental threats, i.e., global warming and pollution. The concept of sustainability becomes broad. Baumgartner and Quaas (2010) defined sustainability economics as being ethically founded in the idea of not wasting scarce resources while achieving the two normative goals of (1) the fulfilling of the desires of the current population and (2) justice, including justice between the present and future generations and justice towards nature. Likewise, Sabapathy (2007) defined it as a permanent economic and social improvement that respects the limits of the Earth's ecologies and meets everyone's needs and aspirations for a better quality of life, now and for future generations.

Literature has extensive empirical studies on the relationship between economic development, energy consumption, and the environment. Tiba and Omri (2017) briefly summarized around 400 studies in this research area. ${ }^{1}$ They reported only two studies, Al-Iriani, 2006; Salahuddin and Gow, 2014, which explored the relationship among these variables in the Gulf Cooperation Council (GCC) countries as a group. ${ }^{2}$ On the other hand, one of the new promising research strands of environmental sustainability is the ecological intensity of well-being (EIWB). It refers to the pressure placed on the environment per unit of human well-being (Dietz et al., 2009, 2012; Knight and Rosa,

\footnotetext{
${ }^{1}$ Similarly, Kais and Sami (2016) summarized around 27 studies from the same area of research. For more recent work in the same research strand, see Sethi et al. (2020) and Long and Ji (2019).

2 Tiba \& Omri (2017) reported two single studies about Saudi Arabia, Alkhathlan et al. (2012) and Alkhathlan and Javid (2013), and one single study about UAE, Shahbaz et al. (2014).
} 
2011; Jorgenson, 2014; Jorgenson et al., 2014). Tiba and Omri's (2017) review did not report any study that used the EIWB indicator in its model. However, literature shows that Sweidan (2018) and Sweidan and Alwaked (2016) explored the effect of economic growth and performance on the GCC and MENA regions' environmental sustainability. Both studies showed that economic development and performance rose the environmental stress or economic unsustainability in these countries.

Researchers, i.e., Dietz et al., 2012; Jorgenson et al., 2014, defined environmental sustainability as the ratio of ecological footprint, i.e., $\mathrm{CO}_{2}$ emissions per capita, to life expectancy at birth. ${ }^{3}$ Technically, it represents the ratio of the stress on the environment to human well-being. More efficient or sustainable countries have small ratios, while less efficient nations have large ratios. Usually, researchers are interested in answering the following important question: How can economic development shape the EIWB or environmental sustainability? According to economic philosophy, economic development seeks to improve human well-being. However, economic growth generates environmental stress, i.e., pollution and climate change, that negatively affects human well-being. Our paper investigates empirically if environmental stress influences the GCC countries' economic growth. The paper is motivated by the fact that $\mathrm{CO}_{2}$ emissions per capita and the environmental stress are high in the GCC countries compared to other nations. Technically, we raise the opposite question of Sweidan (2018) and Sweidan and Alwaked (2016). Based on our knowledge, the literature lacks such a critical study. We claim it is the first study that explores this question in the GCC countries, mainly using the structure

\footnotetext{
${ }^{3}$ Some researchers defined it as the ratio of a country's total energy consumption divided by its gross domestic product.
} 
of environmental stress variable. The GCC countries have a severe lack of environmental studies. Thus, our paper contributes to the literature by filling this gap.

We model environmental stress (sustainability) as an input in the production function. We implicitly assume it has an impact on economic growth. The environmental stress is a proxy of exhausting (use) the nation's resources to generate more welfare. Alternatively, environmental stress is initially generated by economic development. Hence, we explore it's influence on economic growth as a feedback effect. If environmental stress has a positive impact on economic growth, it indicates that the positive side of draining resources outweigh its negative ones. On the contrary, if the influence is negative, then the adverse impacts are larger than the positive ones, and the nation should adopt emergency actions, i.e., efficient allocation of resources, to alter the current situation. This paper is organized as follows. Section 2 reviews relevant literature. Section 3 presents some facts about the GCC countries' $\mathrm{CO}_{2}$ emissions and policy actions. Section 4 introduces the data and methodology of our paper. Section 5 discusses the empirical estimations and the results. Conclusions and policy implications are made in section 6.

\section{Literature Review}

Tiba and Omri (2017) conducted an extensive literature survey on the relationships between energy, environment, and economic growth. This area of research can be divided into three different directions. First, exploring the relationship between energy indicators and economic growth. It assumes a bi-directional causality link between economic performance and energy consumption. Second, investigating the existence of the Environmental Kuznets Curve (EKC). Third, examining the relationship between 
economic growth, energy consumption, and $\mathrm{CO}_{2}$ emissions. ${ }^{4}$ Tiba and Omri (2017) survey confirmed the link between economic growth, energy consumption, and $\mathrm{CO}_{2}$ emissions. Technically, our paper contributes to the third direction of empirical research. Nevertheless, it differs from the previous studies by the structure of the primary variable that measures economic sustainability.

Table (1) presents the previous studies of this research strand in the GCC and MENA countries. The information of Table (1) raises the following notes. First, the number of studies in the area of economic growth, energy consumption, and the environment of the GCC and MENA regions is limited. It may be explained by data availability. The current studies' trend reveals a definite increase. It seems scholars are interested to understand the relationship between the region's above-mentioned variables. Second, most of the studies explored the relationship between economic growth, energy consumption, and $\mathrm{CO}_{2}$ emissions. Nevertheless, Sweidan (2018) and Sweidan and Alwaked (2018) examined the influence of economic development and performance on economic sustainability. So, it is the proper time to move forward and explore the effect of environmental stress on economic growth to complete the knowledge. Third, the previous studies confirmed a link between economic growth, energy consumption, and $\mathrm{CO}_{2}$ emissions in the GCC countries and the MENA region. Furthermore, economic development and performance in the area rise environmental stress.

\section{GCC Countries: $\mathrm{CO}_{2}$ Emissions}

The GCC countries, Bahrain (BA), Kuwait (KW), Oman (OM), Qatar (QA), Saudi Arabia (SA), and the United Arab Emirates (UA), are positioned at the heart of the world

\footnotetext{
${ }^{4}$ For more details about the results of these studies, see Tiba \& Omri (2017).
} 
Table (1): A summary of the previous studies in the MENA and GCC countries

\begin{tabular}{|c|c|c|c|c|c|}
\hline No. & Study & Countries & Period & Methodology & Results \\
\hline 1 & $\begin{array}{l}\text { Mahmood et al. } \\
\text { (2020) }\end{array}$ & Saudi Arabia & $1968-2014$ & ARDL model & $\begin{array}{l}\text { Industrialization and urbanization } \\
\text { disrupt the environment. }\end{array}$ \\
\hline 2 & Sweidan (2018) & $\begin{array}{l}13 \text { MENA } \\
\text { countries }\end{array}$ & $1995-2013$ & Panel analysis & $\begin{array}{l}\text { The economic performance increases the } \\
\text { environmental stress. }\end{array}$ \\
\hline 3 & Sbia et al. (2017) & UAE & 1975-2011 & $\begin{array}{l}\text { ARDL model and } \\
\text { VECM Granger } \\
\text { causality }\end{array}$ & $\begin{array}{l}\text { A bi-directional causality between } \\
\text { electricity consumption and economic } \\
\text { growth. The EKC hypothesis exists in } \\
\text { the UAE. }\end{array}$ \\
\hline 4 & $\begin{array}{l}\text { Sweidan \& Al } \\
\text { Waked (2016) }\end{array}$ & $\begin{array}{l}\text { The GCC } \\
\text { countries }\end{array}$ & $1995-2012$ & Panel analysis & $\begin{array}{l}\text { The economic development increases the } \\
\text { environmental stress. }\end{array}$ \\
\hline 4 & $\begin{array}{l}\text { Al-Iriani \& } \\
\text { Trabelsi (2015) }\end{array}$ & $\begin{array}{l}\text { The GCC } \\
\text { countries }\end{array}$ & $1980-2011$ & $\begin{array}{l}\text { Time series and } \\
\text { panel analyses }\end{array}$ & $\begin{array}{l}\text { A causality relationship exists, but not } \\
\text { homogeneous in all countries. }\end{array}$ \\
\hline 6 & $\begin{array}{l}\text { Al-Mulali \& } \\
\text { Ozturk (2015) }\end{array}$ & $\begin{array}{l}14 \text { MENA } \\
\text { countries }\end{array}$ & 1996-2012 & $\begin{array}{l}\text { Panel analysis and } \\
\text { the fully modified } \\
\text { ordinary least } \\
\text { square (FMOLS) }\end{array}$ & $\begin{array}{l}\text { Energy consumption, urbanization, trade } \\
\text { openness and industrial development } \\
\text { increase environmental damage. }\end{array}$ \\
\hline 7 & $\begin{array}{l}\text { Salahuddin \& } \\
\text { Gow (2014) }\end{array}$ & $\begin{array}{l}\text { The GCC } \\
\text { countries }\end{array}$ & 1980-2012 & $\begin{array}{l}\text { Granger causality } \\
\text { test. }\end{array}$ & $\begin{array}{l}\text { The economic growth does not Granger } \\
\text { cause CO } 2 \text { emissions, but economic } \\
\text { growth Granger cause energy } \\
\text { consumption. }\end{array}$ \\
\hline 8 & Sbia et al. (2014) & UAE & 1975-2011 & $\begin{array}{l}\text { ARDL model and } \\
\text { VECM Granger } \\
\text { causality }\end{array}$ & $\begin{array}{l}\text { A bidirectional causality between } \mathrm{CO} 2 \\
\text { emissions and economic growth, and a bi- } \\
\text { directional causality between } \mathrm{CO} 2 \\
\text { emissions and energy consumption. }\end{array}$ \\
\hline 9 & $\begin{array}{l}\text { Shahbaz et al. } \\
(2014)\end{array}$ & UAE & 1975-2011 & ARDL model & $\begin{array}{l}\text { The EKC hypothesis exists in the UAE. } \\
\text { Economic growth Granger cause } \mathrm{CO} 2 \\
\text { emissions. A positive relationship } \\
\text { between urbanization and } \mathrm{CO} 2 \text { emissions. }\end{array}$ \\
\hline 10 & Ozcan (2013) & $\begin{array}{l}12 \text { MENA } \\
\text { countries }\end{array}$ & $1990-2008$ & $\begin{array}{l}\text { Panel cointegration } \\
\text { test and the FMOLS }\end{array}$ & $\begin{array}{l}\text { Support the EKC hypothesis in UAE, } \\
\text { Egypt, and Lebanon. }\end{array}$ \\
\hline 11 & $\begin{array}{l}\text { Alkhathlan \& } \\
\text { Javid (2013) }\end{array}$ & Saudi Arabia & 1980-2011 & $\begin{array}{l}\text { ARDL and VECM } \\
\text { models }\end{array}$ & $\begin{array}{l}\text { A bidirectional relationship between } \mathrm{CO} 2 \\
\text { emissions and economic growth. }\end{array}$ \\
\hline 12 & Sweidan (2012) & UAE & 1973-2008 & ARDL model & $\begin{array}{l}\text { In the short-run, a bidirectional } \\
\text { relationship between energy consumption } \\
\text { and real output. In the long-run, a } \\
\text { unidirectional relationship from real } \\
\text { output to energy consumption. }\end{array}$ \\
\hline 13 & $\begin{array}{l}\text { Alkhathlan et al. } \\
\text { (2012) }\end{array}$ & Saudi Arabia & 1980-2008 & $\begin{array}{l}\text { ARDL and VECM } \\
\text { models }\end{array}$ & $\begin{array}{l}\text { In the long run, output leads to greater } \\
\mathrm{CO} 2 \text { emissions. }\end{array}$ \\
\hline 14 & Mehrara (2007) & $\begin{array}{l}11 \text { oil exporting } \\
\text { countries, } \\
\text { including } 5 \\
\text { GCC countries }\end{array}$ & 1971-2002 & Panel cointegration & $\begin{array}{l}\text { A unidirectional from output to energy } \\
\text { consumption. }\end{array}$ \\
\hline 15 & Squalli (2007) & OPEC members & $1980-2003$ & ARDL model & $\begin{array}{l}\text { A bidirectional relationship between } \\
\text { energy consumption and output. }\end{array}$ \\
\hline 16 & Al-Iriani (2006) & $\begin{array}{l}\text { The GCC } \\
\text { countries }\end{array}$ & $1971-2002$ & Panel cointegration & $\begin{array}{l}\text { A unidirectional from output to energy } \\
\text { consumption }\end{array}$ \\
\hline
\end{tabular}

Source: Compiled by the authors.

and located in the Arabian Peninsula. Their total population number is 58.0 million in

2019, which is around $0.8 \%$ of the world's population. They are abundant in natural

resources, including massive supplies of natural gas and crude oil. The British petroleum

statistical review of the world energy for June 2020 reported that these countries own 
around $30.5 \%$ and $19.6 \%$ of the world's proven oil and gas reserves, respectively. Consequently, these countries rely heavily on oil and gas sales revenues to enhance economic development, amend social and health indicators, and build a first-class infrastructure. There is no doubt that the oil revenues contribute positively to the public well-being in the GCC countries. For example, the average annual income per capita during the period (1995-2018) is around $\$ 40$ thousands. Moreover, the average life expectancy at birth increased from 72.8 years in 1995 to 77.2 years in 2018 .

The World Bank development indicators display that the GCC countries' average contribution to the world $\mathrm{CO}_{2}$ emissions reached $2.3 \%$ during the period (1995-2014). Table (2) presents and compares the $\mathrm{CO}_{2}$ emissions per capita between the GCC countries and three industrial countries (France, Japan, and the UK) for the period (19952016). On average, Table (2) tells that the $\mathrm{CO}_{2}$ emission per capita in these countries is higher than that of the industrial countries by more than three times. The extensive $\mathrm{CO}_{2}$ emissions cause global climate change and pollution. Figure (1) presents the $\mathrm{CO}_{2}$ emissions per capita for the GCC countries during the same period. It displays that the $\mathrm{CO} 2$ emission of these countries is fluctuating but has a descending trend. It is also higher than that of some industrial countries with a higher number of populations. The global ecological footprint can also be a useful indicator for understanding and comparing the environmental threats and challenges on the regional and global levels. Table (3) introduces and compares the ecological footprint of consumption per person of the GCC countries and other countries in 2021 based on data from 2017. The ecological footprint of all the GCC countries is higher than that of the world average (2.8 gha/person). Further, the individual GCC countries have a higher ecological footprint of consumption compared with individual developed and emerging countries. Furthermore, 
Qatar (14.6 gha/person) and Luxembourg (12.8 gha/person) have the highest ecological footprint of consumption worldwide.

Figure (1): The $\mathrm{CO} 2$ emission per capita of the

GCC countries during the period (1995-2016)

(metric tons)

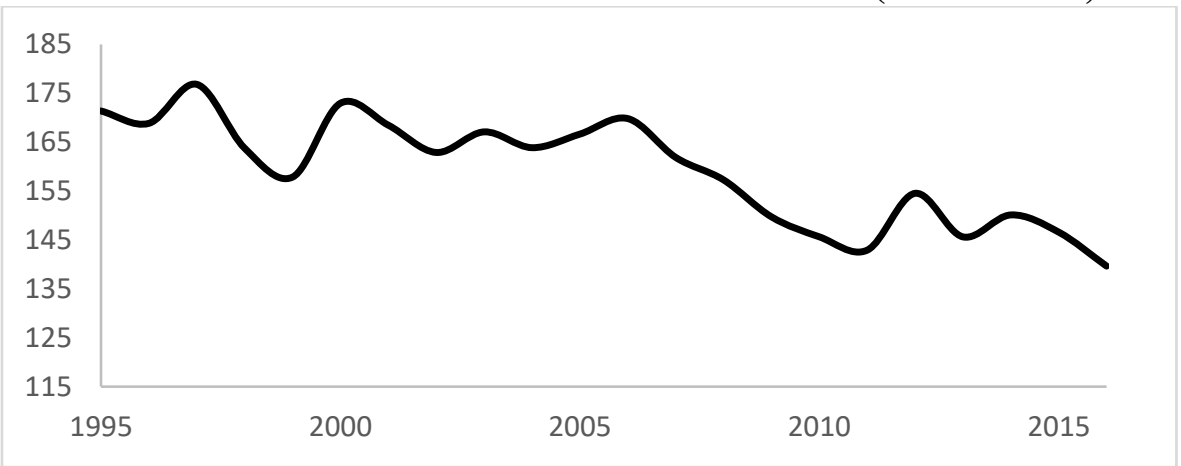

Source: The World Bank Development Indicators.

Table (2): The CO2 emissions per capita (metric tons) of the GCC countries and three industrial countries

\begin{tabular}{|lccccccccc|}
\hline Years & Bahrain & Kuwait & Oman & Qatar & $\begin{array}{c}\text { Saudi } \\
\text { Arabia }\end{array}$ & UAE & Japan & France & UK \\
& & & & & & & & \\
$\mathbf{1 9 9 5}$ & 26.29 & 34.04 & 7.21 & 61.91 & 12.55 & 28.85 & 9.43 & 5.86 & 9.28 \\
$\mathbf{2 0 0 0}$ & 28.05 & 26.12 & 9.65 & 58.64 & 14.3 & 35.68 & 9.62 & 5.95 & 9.2 \\
$\mathbf{2 0 0 5}$ & 21.60 & 31.43 & 11.90 & 58.92 & 16.63 & 25.36 & 9.70 & 6.10 & 8.98 \\
$\mathbf{2 0 1 0}$ & 23.59 & 29.89 & 15.59 & 40.74 & 18.91 & 19.44 & 9.15 & 5.43 & 7.86 \\
$\mathbf{2 0 1 4}$ & 23.45 & 25.22 & 15.44 & 45.42 & 19.53 & 23.30 & 9.54 & 4.57 & 6.50 \\
$\mathbf{2 0 1 6}$ & 22.23 & 24.95 & 14.17 & 38.90 & 17.37 & 22.04 & 8.94 & NA & 5.78 \\
Avg. & $\mathbf{2 4 . 0 9}$ & $\mathbf{2 8 . 8 4}$ & $\mathbf{1 2 . 5 5}$ & $\mathbf{5 3 . 1 5}$ & $\mathbf{1 5 . 8 5}$ & $\mathbf{2 3 . 7 1}$ & $\mathbf{9 . 4 6}$ & $\mathbf{5 . 7 5}$ & $\mathbf{8 . 2 6}$ \\
\hline
\end{tabular}

Source: The World Bank Development Indicators via the data stream.

Table (3): The ecological footprint of consumption per person of the GCC countries and other countries in 2021

(Global hectares per person)

\begin{tabular}{|lccc|}
\hline Countries & $\begin{array}{c}\text { Ecological foot } \\
\text { (consumption) }\end{array}$ & Countries & $\begin{array}{c}\text { Ecological foot } \\
\text { (consumption) }\end{array}$ \\
Bahrain & 8.7 & China & 3.7 \\
Kuwait & 8.0 & Italy & 4.4 \\
Oman & 7.3 & Japan & 4.7 \\
Qatar & 14.6 & Turkey & 3.5 \\
Saudi Arabia & 5.7 & UK & 4.2 \\
United Arab & & USA & 8.1 \\
Emirates & 8.9 & Luxembourg & 12.8 \\
Canada & 8.1 & The World & 2.8 \\
\hline
\end{tabular}

Source: The National Footprint Account Edition 2021. 
The Intergovernmental Panel on Climate Change (IPCC) has published many reports about climate change over many years. It assured that global warming is an observable fact and a severe problem. They also warned that there is rising in the temperature of lands and oceans and more frequent heatwaves in most land regions. These dangerous developments will increase poverty and starvation levels, and human health suffers. The reports also warned the Middle East region of a high risk of drought if the region's temperature increased by more than 1.5 degrees Celsius. Further, the Arab Forum for environment and development (AFED) confirmed the GCC countries' low air quality. ${ }^{5}$ Air pollution's primary sources are industrial and vehicle emissions, electric power generations, and inappropriate disposal of solid and hazardous waste. Furthermore, Heesterman (2020) confirmed that many of the world's wealthy coastal cities which historically developed as ports will disappear below the sea level. The quick solution to avoid the climate change catastrophic effects is to limit the $\mathrm{CO} 2$ emissions. It requires a unique degree of international cooperation, a high level of taxation on the extraction of coal and crude oil, and the use of pressurized liquid petrol gas as aviation fuel.

\subsection{The Governments' Actions}

What did the GCC countries do to face regional and global environmental threats and challenges? We can highlight the answer via three dimensions. First, on the institutional level, they have well-established institutional arrangements to achieve sustainable development and protect the environment. The GCC governments' policies and action plans have the following levels: individual country actions, the GCC countries

\footnotetext{
${ }^{5}$ For detailed information, see AFED (2008).
} 
arrangements via the GCC general secretariat ${ }^{6}$, the League of Arab States decisions via the economic and social council. ${ }^{7}$ Second, the GCC countries relied on economic diversification as an extra strategic tool to confront the effects of climate change and boost economic growth. They realized that global warming harms non-oil economic sectors, i.e., agriculture, infrastructure, and tourism. Accordingly, the GCC countries' governments intervened via their strategic visions to support these sectors, preserve the environment, and enhance economic growth (Al-Sarihi, 2018). Further, these countries recognized that the oil sector is finite and experience considerable fluctuations in the oil demand. So, it creates unstable oil prices and weak government revenues. Besides, oil revenues crowd out the other economic sectors. All the GCC countries have currently included an environmental dimension, i.e., energy efficiency, in their long-term development plans. ${ }^{8}$ Third, the GCC countries added a market-based instrument (energy price reforms) starting from 2015 to protect the environment and ration energy consumption. Thus, these countries' energy subsidies have fallen from $\$ 116$ billion in 2014 to $\$ 47$ billion in 2016 (IMF; 2017).

Did the above-mentioned policy actions were enough to generate adequate environmental protection? The answer can be highlighted by the Arab Forum for Environment and Development (AFED) public opinion surveys. They explored the Arab public awareness of environmental threats because of climate change. The AFED performed three surveys in 2006, 2009, and 2017 that covered all the Arab countries. The same main conclusions were reached by the surveys.

\footnotetext{
${ }^{6}$ The GCC countries' organization structure consists of the following three units: the supreme council, the ministerial council, and the secretariat general.

${ }^{7}$ For more details about the League of Arab States' institutional arrangements, see Abdel Gelil (2017).

${ }^{8}$ For more details, see Al-Sarihi (2018), pages 17-23.
} 
The surveys found that 98 percent of the respondent believed that the climate is changing, and 89 percent considered this was due to human activities, including excessive use of energy. Survey respondents expressed their willingness to participate in environmental actions to guard the environment. More importantly, it found that practically no work is being implemented to prepare the Arab countries for climate change threats. Technically, there were no research efforts to investigate the effects of climate change on health, infrastructure, biodiversity, tourism, water, and food production. Moreover, the Arab public alleged that the environment has continued to deteriorate over the last ten years. The public said that some governments had initiated specific policies that promoted green and sustainable economy, but these procedures are not enough to tackle the threats.

\subsection{Data, Model, and Methodology}

\subsection{Data and Model}

Our paper uses perfectly balanced data of the six GCC countries covering the period (1995-2016) and consists of 132 observations. The data's source is the World Bank World Development Indicators (WBWDI) via Data Stream. This paper uses the idea of the Cobb-Douglas production function to achieve its goal. ${ }^{9}$ Nevertheless, we adjust the model to be consistent with the GCC countries' case. The GCC countries are endowed with natural resources, mainly oil and gas. Their incomes are generated based on two items: the rents of natural resources and these resources' use (the stress). Alternatively, economic growth is generated basically from extracting and consuming the natural resources in these countries. As a result, the income per capita is a function of the rent of the total natural resource and environmental stress. The specification of the current paper's model as follows:

\footnotetext{
${ }^{9}$ For more details, see Mankiw et al. (1992) and Romer (1990).
} 


$$
Y_{i t}=A_{0} R_{i t}^{\theta} S_{i t}^{\gamma}
$$

Where $Y_{i t}$ is the income per capita in the country $\mathrm{i}$ at time t, $A_{0}$ indicates the parameter of the technology progress indicator or total factor productivity, $R_{i t}$ represents the rent of the natural resources in the country $i$ at time t. It includes the sum of oil rents, natural gas rents, coal rents, mineral rents, and forest rents. $S_{i t}$ is the environmental stress in the country $\mathrm{i}$ at time $\mathrm{t}$, and $\theta$ and $\gamma$ are the model's parameters or the factors of production shares. Based on economic theory, the expected signs of $\theta$ could be positive or negative, and it depends on the validity of the resources curse hypothesis. For example, Adekoya (2020) found that the economic growth of the resource-rich countries adversely responds to oil consumption in the long-run, while the short-run impact is positive. Likewise, Dell'Anno (2020) concluded that resource dependence has three effects (positive, negative, and insignificant) on Iran's economic growth. In the same vein, Abdulahi et al. (2019) confirmed that resource rents impede economic growth conditional on using a threshold value of institutional quality based on data from 14 resource-rich countries of sub-Saharan Africa. Similarly, what is the expected sign of $\gamma$, and how can we interpret it? The logical answer is that $\gamma$ could be positive or negative too. What is the meaning of a positive impact of environmental stress on the GCC countries' economy? We think the interpretation is related to how we design the environmental stress indicator. In our paper, we defined environmental stress as $\mathrm{CO} 2$ emissions divided by life expectancy. Environmental stress can be interpreted as a sign to boost economic activity. If the economic development process succeeded in increasing human well-being more than wasting the resources (the stress), we should expect a positive sign. However, if the economic activities enhanced wasting the resources more than human well-being, we should expect a negative sign. There are no previous warning lights in the GCC countries 
tell that the pollution reached a very high level. Thus, the governments did not adopt emergency actions or procedures. As a result, the governments did not implement any sudden environmental policy that negatively affected economic growth. It indicates that the GCC governments' actions in the environmental area is not sufficient.

We transform equation (1) into the log-linear equation. So, the new form of equation (1) is:

$\operatorname{Ln} Y_{i t}=\operatorname{Ln} A_{0}+\theta \operatorname{Ln} R_{i t}+\gamma \operatorname{Ln} S_{i t}$

We can rewrite equation (2) in an econometric form as follows:

$L n Y_{i t}=a_{0}+\theta L n R_{i t}+\gamma L n S_{i t}+U_{i t}$

where $a_{0}$ is the intercept and $U_{i t}$ is the error term.

The GCC countries have a constraint on data availability. Thus, we employ the best available choices to estimate the model of equation (3). It justifies why our study covers the period (1995-2016). Researchers in environmental economics paid attention to an important issue when using a ratio as an indicator in the regression analysis. This issue is related to the construction of the ratio. This complication can be described as follows: the variability and the range of the numerator and denominator of the ratio can differ significantly. Thus, the indicator can be dominated by either the former or the latter. In our data illustration, the coefficient of variation (standard deviation divided by the mean) of the $\mathrm{CO}_{2}$ emissions per capita is 0.52 , and its range is $6.7-70.0$ metric tons per capita. As for life expectancy, the variation coefficient is 0.03 , and its range is 69.8-79.9 years. The two variation coefficients tell that the relative movements in the $\mathrm{CO}_{2}$ emissions per capita, the numerator, are much larger than the variation in life expectancy, the denominator. It indicates that variation in the numerator is driving the variation of the indicator. As a result, we should resolve this complication before using the ratio in our 
regression analysis. We follow researchers from the New Economics Foundation (2009) to solve the problem. The solution method consists of forcing the numerator and denominator's variation coefficient to be equal by adding a constant number to one of them. It shifts the mean without altering the variance. It means the variation coefficient of the two variables will be equal. This technique was used by many researchers in the environmental economics area, i.e., Sweidan, 2018; Sweidan and Alwaked, 2016; Jorgenson et al., 2014; Dietz et al., 2012. We equate the coefficients of variation for the two variables in our data sample by adding the correction factor $462.47^{10}$ to the $\mathrm{CO} 2$ emissions per capita. Therefore, the adjusted $S_{i t}$ is computed by the following formula:

$S_{i t}=\left(\frac{\left[\text { CO2 emissions per } \text { capita }_{i t}+462.47\right]}{\text { Life expectancy }}\right) * 100$

Figure (2) presents the adjusted $S_{i t}$ of the GCC countries over the period (1995-2016). It reveals that the adjusted $S_{i t}$ has a declining trend, which means that human well-being is larger than environmental stress. Despite the massive $\mathrm{CO} 2$ emissions in the GCC countries, they can mitigate its negative impacts on the economy by expanding public welfare. Table (4) presents the descriptive statistics of the variables included in the current paper model.

\subsection{Methodology}

Our paper employs the Panel Autoregressive Distributed Lagged (ARDL) model introduced by Pesaran et al. (1999) to extract the empirical evidence. It detects the presence of a long-run relationship between the variables in the model. It computes shortrun and long-run coefficients and estimates the speed of adjustment (error correction term) toward the long-run equilibrium. This approach is valid regardless of the variables'

\footnotetext{
${ }^{10}$ The correction factor is estimated based on the following formula, $C F=\left[\left(S_{C O 2} * M_{L E}\right) / S_{L E}\right]-M_{C O 2}$, where $\mathrm{S}$ stands for the standard deviation, $\mathrm{M}$ denotes the mean, $\mathrm{CO}_{2}$ is the emissions per capita, and $\mathrm{LE}$ indicates the life expectancy.
} 
Figure (2): The environmental stress, $L n S_{i t}$, of the

GCC countries during the period (1995-2016)

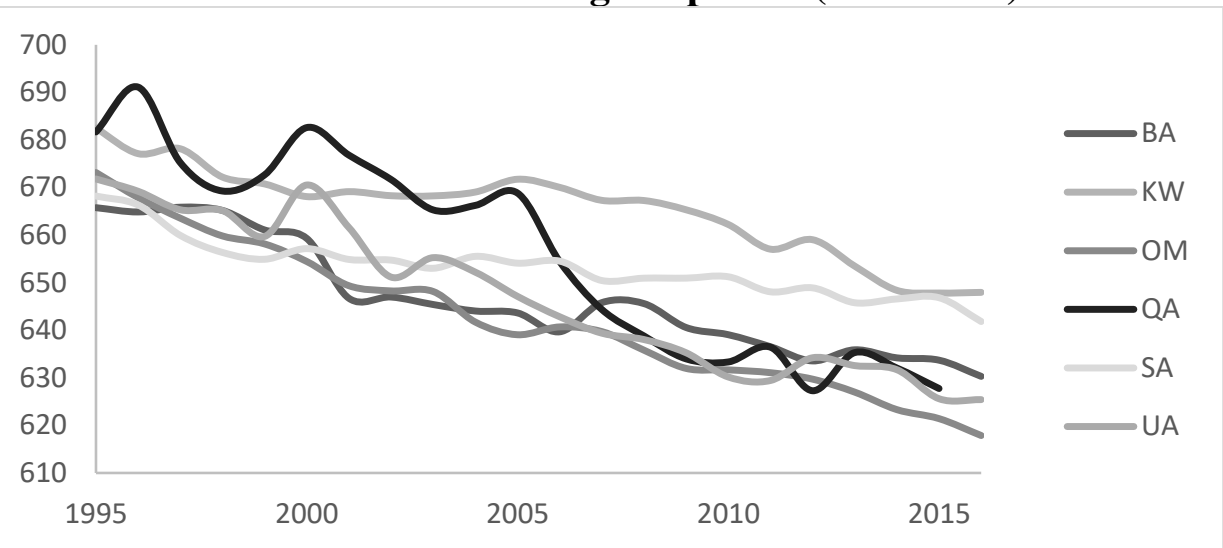

Source: computed by the authors.

Table (4): Descriptive statistics

\begin{tabular}{|ccccc|}
\hline Variable & Mean & $\begin{array}{c}\text { Standard } \\
\text { deviation }\end{array}$ & Min & Max \\
\hline$L n Y_{i t}$ & 10.34 & 0.49 & 9.70 & 11.15 \\
$L n R_{i t}$ & 3.15 & 1.62 & -0.58 & 5.70 \\
$L n S_{i t}$ & 6.48 & 0.03 & 6.43 & 6.54 \\
$L n S G_{i t}$ & 6.30 & 0.02 & 6.26 & 6.35 \\
$L n S P_{i t}$ & 5.66 & 0.04 & 5.56 & 5.75 \\
\hline
\end{tabular}

Source: computed by the authors.

integration orders. It is applicable if the orders of the variables are I (0) or I (1) or I (0) and I (1), but not I (2). The general specification of the ARDL (p, q) model is as follows:

$Y_{i t}=\alpha_{i}+\sum_{j=1}^{p} \beta_{i j} Y_{i, t-j}+\sum_{j=0}^{q} \dot{\theta}_{i j} X_{i, t-j}+\varepsilon_{i t}$

where $Y_{i t}$ denotes the independent variable for a group of countries $\mathrm{i}, X_{i t}$ indicates a list of explanatory variables for a group of countries i, $\alpha_{i t}$ stands for the fixed effect, $\beta_{i j}$ and $\dot{\theta}_{i j}$ represent the estimated coefficients, $\varepsilon_{i t}$ is the random disturbance. Pesaran et al. (1999) rewrite equation (5) to match the panel error correction form:

$$
\Delta Y_{i t}=\mu_{i}+\varphi_{i} Y_{i, t-1}+\vartheta_{i} X_{i, t-1}+\sum_{j=1}^{p-1} \gamma_{i j} \Delta Y_{i, t-j}+\sum_{j=0}^{q-1} \rho_{i j} \Delta X_{i, t-j}+\epsilon_{i t}
$$


where $\varphi_{i}$ and $\vartheta_{i}$ are the long-run parameters, and we employ them to estimate the speed of adjustment (error correction term) to long-run steady-state, $\gamma_{i j}$ and $\dot{\rho}_{i j}$ are the shortrun coefficients lagged dependent and independent variables, respectively. We write the paper's model by using the variables' notations in equation (6) as follows:

$$
\begin{aligned}
& \Delta L n Y_{i t}=\emptyset_{0}+\emptyset_{1} L n Y_{t-1}+\emptyset_{2} L n R_{t-1}+\emptyset_{3} L n S_{t-1}+\sum_{i=1}^{p-1} \omega_{1} \Delta L n Y_{t-i}+\sum_{i=0}^{q-1} \omega_{2} \Delta L n R_{t-i}+ \\
& \sum_{i=0}^{q-1} \omega_{3} \Delta L n S_{t-i}+u_{i t}
\end{aligned}
$$

\subsection{Panel unit root tests}

The first step in the estimation process is to check the stationarity of our model's dependent and independent variables. It guarantees that our variables satisfy the condition of the variables' order. We conduct three panel unit root tests: Levin, Lin, and Chu (LLC) unit root test, Breitung test, and Pesaran test. The last test is classified among the secondgeneration unit root tests, which allow for cross-sectional dependence. Nevertheless, the first two tests do not have this feature. The $H_{0}$ for the LLC and Breitung test tells that the panels contain unit roots, against the $H_{1}$, i.e., the panels are stationary. Whereas, the $H_{0}$ for Pesaran test states that all panels are nonstationary. We report the results of the three panel unit root tests in Table (5). The results display that some variables are stationary at the level and/ or at the first difference. Thus, we can use the panel ARDL approach.

\section{Empirical estimation}

\subsection{Panel cointegration tests}

We explore the presence of a long-run relationship among the variables using Pedroni (1999, 2004) and Westerlund (2005) panel cointegration tests. These two tests have the same null hypothesis of no cointegration. Pedroni (1999, 2004) alternative hypothesis states that all panels are cointegrated. Whereas, the alternative hypothesis of Westerlund (2005) is that some panels are cointegrated. We present the panel cointegration tests' 
results in Table 6 . We perform the two cointegration tests by including fixed effect, trend and remove the cross-sectional means. The two tests' results reject the null hypothesis of no cointegration in favor of the existence of a long-run relationship between our variables.

Table (5): Panel unit root tests

\begin{tabular}{|cccc|}
\hline Variables & LLC & Breitung & Pesaran \\
\hline$L n Y_{i t}$ & $-2.73^{* * *}$ & $0.87^{* * *}$ & -1.12 \\
$\Delta L n Y_{i t}$ & $-2.39^{* * *}$ & $-4.06^{* * *}$ & $-2.78^{*}$ \\
$L n R_{i t}$ & 2.06 & 2.84 & -1.29 \\
$\Delta L n R_{i t}$ & $-1.46^{*}$ & $-2.34^{* * *}$ & $-3.39^{* * *}$ \\
$L n S_{i t}$ & $-1.65^{* *}$ & $-1.98^{* *}$ & -2.36 \\
$\Delta L n S_{i t}$ & $-5.51^{* * *}$ & $-5.93^{* * *}$ & $-4.39^{* * *}$ \\
$L n S G_{i t}$ & -0.60 & $-1.33^{*}$ & -2.07 \\
$\Delta L n S G_{i t}$ & $-3.62^{* * *}$ & $-4.73^{* * *}$ & $-4.77^{* * *}$ \\
$L n S P_{i t}$ & $-4.1^{* * *}$ & $-1.43^{*}$ & $-3.18^{* * *}$ \\
$\Delta L n S P_{i t}$ & $-7.45^{* * *}$ & $-6.67^{* * *}$ & $-4.75^{* * *}$ \\
\hline
\end{tabular}

Notes:

The LLC test Includes: trend, panel means, and remove cross sectional mean.

The Breitung test includes trend, panel means, remove cross sectional mean, and allow for cross sectional dependence.

$* * * \mathrm{P}<0.01, * * \mathrm{P}<0.05$, and $* \mathrm{P}<0.10$.

Table 6. Panel cointegration tests

\begin{tabular}{|cc|}
\hline \multicolumn{1}{|c|}{ Tests } & With fixed effect and trend \\
\hline Pedroni test for cointegration & \\
Phillips-Perron t & $2.07^{* *}$ \\
Modified Phillips-Perron t & $2.35^{* * *}$ \\
Augmented Dickey-Fuller t & $1.94^{* *}$ \\
Westerlund test for cointegration & \\
Variance ratio & $1.88^{* *}$ \\
\hline
\end{tabular}

Note: *** $\mathrm{P}<0.01, * * \mathrm{P}<0.05$, and $* \mathrm{P}<0.10$.

Cross-sectional means are removed. 


\subsection{The Results}

The presence of a long-run relationship between the variables indicates we can estimate the ARDL model of equation (7). There are three estimators: pooled mean group (PMG), mean group (MG), and dynamic fixed effect (DFE). The PMG estimator levies homogeneity restriction on the long-run coefficients across counties while maintaining heterogeneity for the intercept and short-run parameters. In contrast, the MG does not place any restrictions. It allows all parameters to change and to be heterogeneous in the short and long run. While, the DFE estimator imposes homogeneity restriction on the slopes, and the intercepts are allowed to alter across countries. Under the long-run homogeneity assumption, the PMG estimator is more efficient than the MG and DFE estimators (Pesaran et al., 1999). Accordingly, we should find out the most efficient estimator for our data among the three estimators. The direct method is to employ the Hausman test to check if there is a significant difference between PMG and/or MG or PMG and DFE estimators. The PMG estimator is efficient and consistent under the null hypothesis of slope homogeneity. The PMG estimator is recommended if the null hypothesis is not rejected.

The Hausman's test results display that the proper model is PMG. ${ }^{11}$ Thus, we compute the ARDL $(2,0,0)^{12}$ model coefficients by the PMG estimator. For robustness check, we approximate three ARDL model scenarios based on the generated environmental stress and as follows. ${ }^{13}$ Scenario 1 (original model) uses the environmental stress produced

\footnotetext{
${ }^{11} \mathrm{We}$ conduct two Hausman's tests. The first one between PMG and MG estimators, and the second test between PMG and DFE estimators. The Hausman's tests' results (0.41 (Prob. 0.813) and 0.26 (Prob. 0.880 ), respectively) are statistically insignificant in both cases. Thus, the long-run PMG estimator is recommended.

${ }^{12}$ These are the computed optimum lags that minimizing the log likelihood by using the FORVAL programming command.

${ }^{13}$ We consider scenarios 2 and 3 are different sensitivity analyses to scenario 1 .
} 
during the consumption of solid, liquid, and gas fuels and gas flaring $\left(\operatorname{Ln} S_{i t}\right)$. Scenario 2 utilizes the environmental stress generated from natural gas $\left(\operatorname{LnS} G_{i t}\right) .{ }^{14}$ Scenario 3 employs the environmental stress created by petroleum-derived fuels $\left(\operatorname{LnSP} P_{i t}\right) .{ }^{15}$ Figures (3) and (4) present the environmental stress of scenario 2 and scenario 3, respectively.

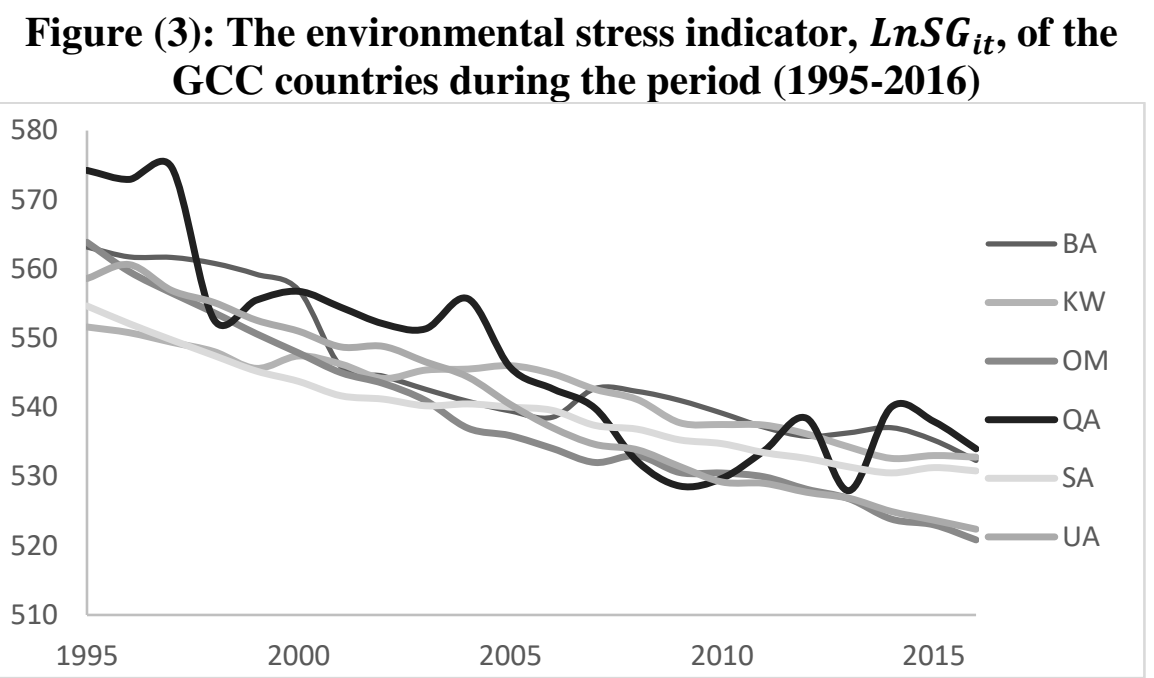

Source: computed by the authors.

Figure (4): The environmental stress indicator, $\operatorname{LnSP} P_{i t}$, of the GCC countries during the period (1995-2016)

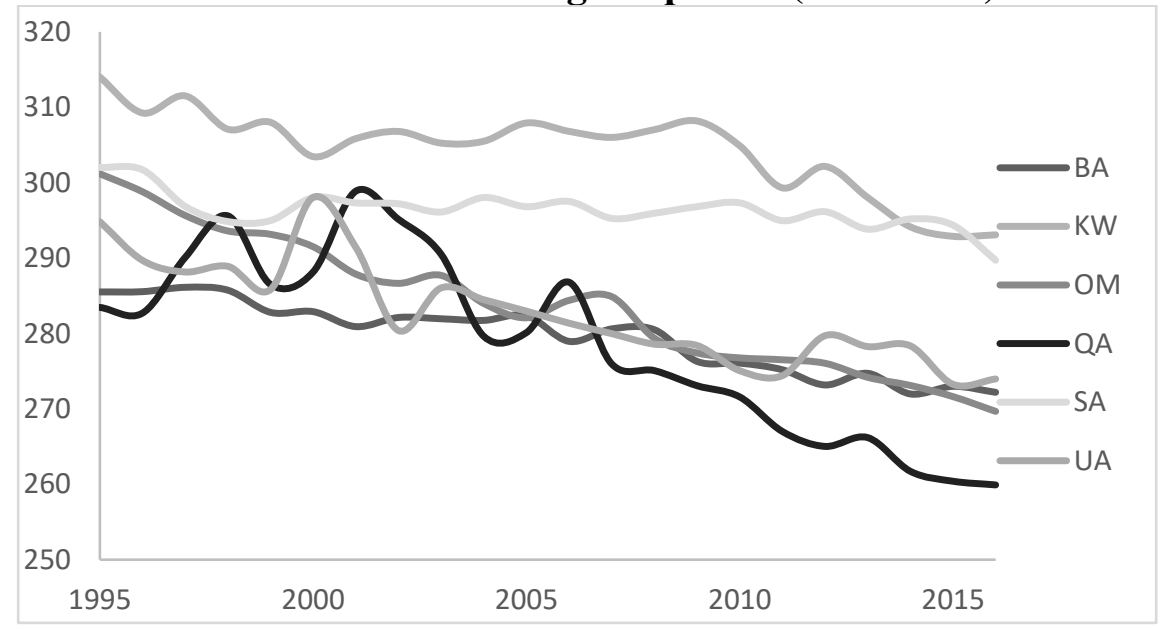

Source: computed by the authors.

\footnotetext{
${ }^{14}$ Scenario 2 Hausman's tests' results (0.94 (Prob. 0.626) and 2.16 (Prob. 0.340), respectively) are statistically insignificant in both cases. Thus, the long-run PMG estimator is recommended.

${ }^{15}$ Scenario 3 Hausman's tests' results (0.28 (Prob. 0.869) and 0.06 (Prob. 0.973), respectively) are statistically insignificant in both cases. Thus, the long-run PMG estimator is recommended.
} 
Table 7 documents the log-term parameters, short-term coefficients, and the error correction terms (ECT) of the three scenarios. These scenarios produced almost very similar results. The ECT in the three scenarios is statistically significant and negative. It approves a converging and stable long-run relationship between the model's variables. The deviations from long-run equilibrium are corrected by an average adjustment speed of 20.3 percent in the current period.

Table 7. The ARDL models' results (PMG), dependent variable $\Delta \operatorname{Ln} Y_{i t}$

\begin{tabular}{|c|c|c|c|}
\hline & Scenario 1 & Scenario 2 & Scenario 3 \\
\hline \multicolumn{4}{|c|}{ The Long-run coefficients } \\
\hline$L n R_{i t}$ & $\begin{array}{r}-0.022 * \\
(0.012)\end{array}$ & $\begin{array}{l}-0.009 \\
(0.014)\end{array}$ & $\begin{array}{c}-0.030 * * * * \\
(0.011)\end{array}$ \\
\hline $\operatorname{LnS} S_{i t}$ & $\begin{array}{c}0.560 * * * * \\
(0.004)\end{array}$ & 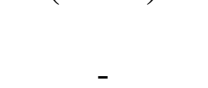 & \\
\hline $\operatorname{LnSG}_{i t}$ & 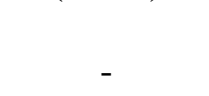 & $\begin{array}{c}0.925 * * * \\
(0.005)\end{array}$ & \\
\hline$L n S P_{i t}$ & - & 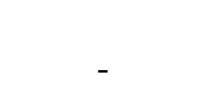 & $\begin{array}{c}0.231 * * * * \\
(0.004)\end{array}$ \\
\hline \multicolumn{4}{|c|}{ The Short-run coefficients } \\
\hline$\Delta L n R_{i t}$ & $\begin{array}{c}0.079 * * * \\
(0.031)\end{array}$ & $\begin{array}{c}0.072 * * * * \\
(0.027)\end{array}$ & $\begin{array}{c}0.082 * * * * \\
(0.031)\end{array}$ \\
\hline$\Delta L n S_{i t}$ & $\begin{array}{c}0.970 \\
(0.660)\end{array}$ & - & - \\
\hline$\Delta L n S G_{i t}$ & - & $\begin{array}{c}3.55^{* * * *} \\
(1.012)\end{array}$ & - \\
\hline$\Delta L n S P_{i t}$ & - & & $\begin{array}{l}-0.064 \\
(0.342)\end{array}$ \\
\hline Constant & $\begin{array}{c}1.243 * * * * \\
(0.478)\end{array}$ & $\begin{array}{c}0.929 * * * * \\
(0.266)\end{array}$ & $\begin{array}{c}1.922 * * * * \\
(0.757)\end{array}$ \\
\hline$E C T_{i t}$ & $\begin{array}{c}-0.187 * * \\
(0.077)\end{array}$ & $\begin{array}{c}-0.207 * * * \\
(0.067)\end{array}$ & $\begin{array}{c}-0.215^{* *} \\
(0.088)\end{array}$ \\
\hline \multicolumn{4}{|c|}{ Hausman test Chi. Sq. [Prob.] } \\
\hline MG vs. PMG & $0.41[0.813]$ & $0.94[0.626]$ & $0.28[0.869]$ \\
\hline DFE vs. PMG & $0.26[0.880]$ & $2.16[0.340]$ & $0.06[0.973]$ \\
\hline Log Likelihood & 234.96 & 238.45 & 233.37 \\
\hline \# of countries & 6 & 6 & 6 \\
\hline \# of Obs. & 132 & 132 & 132 \\
\hline
\end{tabular}

Notes: standard errors are in parentheses. $* * * \mathrm{P}<0.01, * * \mathrm{P}<0.05$, and $* \mathrm{P}<0.10$. 
All the short-run parameters of the natural resources' rents are statistically significant and positive, with an average value of (0.078). In the long run, they continue to be statistically significant, in two scenarios, but with a negative sign. This evidence supports the resources curse hypothesis in the GCC countries. Moreover, the average size of these long-run parameters $(-0.017)$ is smaller than the short-run coefficients. Furthermore, the short-run parameters of environmental stress are statistically insignificant in two scenarios. However, in the long run, all the parameters switched to be statistically significant and positive. It means the GCC countries' environmental stress succeeded in producing positive effects more than negative ones. Hence, the final observable influence is positive. The environmental stress can be viewed in terms of more consumption, investment, economic activity, and higher economic welfare. It may also indicate that these countries' environmental stress did not reach critical levels that produce significant adverse effects. As a result, the GCC countries are lucky because the positive impacts prevail, and these countries should start giving more attention to the environmental stress before any possible enlargement to the negative influences.

We think our results make sense and consistent with the previous studies' results, i.e., Sbia et al., 2017 and 2014; Alkhathlan and Javid, 2013; Sweidan, 2012; Squalli, 2007. They confirmed a bi-directional relationship between $\mathrm{CO} 2$ emissions and economic growth in the GCC countries. From the other direction, Sweidan (2018) and Sweidan and Alwaked (2016) concluded that economic development and performance created more pressure on the environment in the GCC countries and MENA region. Hence, the environmental stress is a proxy to the dynamics of the economic activities, and logically its effect could be positive unless the government took some procedures to reduce the environmental stress, which might adversely affect the economic growth. Overall, our 
paper confirms that the GCC countries' environmental stress contributes positively to economic growth, mainly in the long run.

\section{Conclusions and Policy Implications}

Environmental issues and sustainable development have been attracting the world economic and environmental organizations and scholars alike. Literature has extensive empirical works focused on exploring the relationship between economic development, energy consumption, and the environment. In contrast, there are limited studies focused on the link between environmental stress and economic development. The GCC countries have limited empirical works in this research area. They are oil and gas exporting countries and have around $29.3 \%$ and $21.5 \%$ of the world's proven oil and gas reserves, respectively. They also use oil and gas sales revenues to enhance economic growth, amend social and health indicators, and build a first-class infrastructure. The different economic and health indicators showed clear improvements during the past four decades. However, many reports displayed high $\mathrm{CO}_{2}$ emissions per capita and environmental stress in GCC countries.

Our paper empirically investigates the effect of environmental stress or environmental sustainability on the GCC countries' economic growth. We model the environmental stress as an input in the production function. Our paper's primary motivation is the high $\mathrm{CO}_{2}$ emissions and the environmental stress in the GCC countries relative to other nations. These countries lack such critical study. The literature has two studies, Sweidan (2018) and Sweidan and Alwaked (2016), that explored the opposite question, which is the effect of economic development on the environmental stress in the MENA region and GCC countries. The reports showed that these countries had established a promising institutional framework to deal with environmental and sustainable development. 
Unfortunately, the region lacks genuine interest in environmental issues, which prevent establishing useful work, sound policies, and sustainable development evaluations.

We use the ARDL methodology to estimate our models' parameters. The results reveal that environmental stress has a positive and statistically significant effect on the GCC countries' economic growth, mainly in the long run. To check the robustness of our results, we employ three proxies of environmental stress. The three scenarios generated almost similar results. Our conclusion tells that the GCC countries' environmental stress produced more positive impacts than adverse effects. The environmental stress is a signal for more consumption, investment, and higher economic welfare in the GCC countries. If the economic development mechanics achieved more human well-being than damaging the resources (the stress), then a positive feedback effect is expected. The GCC countries' environmental stress did not reach critical levels that produce vast negative influences on the economy. Historically, the governments did not adopt harsh decisions that hindered economic activities. On the contrary, the GCC governments did not give serious attention to environmental and sustainable development problems. The GCC countries are lucky because the positive impacts prevail. However, economic and environmental policymakers should monitor and evaluate the future environmental stress outcomes in these countries. The positive impacts are not guaranteed to dominate over the long-time. The GCC countries should adopt an efficient energy-environmental policy by shifting to the renewable energy, i.e. wind and solar. This move helps these countries to diversify their energy resources and reduce the environmental stress. These countries have initiated some reforms, i.e., the establishment of research and development centers, ${ }^{16}$ to enhance

\footnotetext{
${ }^{16}$ This includes Masdar City in the United Arab Emirates and King Abdullah City for Atomic and Renewable Energy in Saudi Arabia.
} 
renewable energy deployment. The UAE has initiated its nuclear energy program and built its first power plant in the region. ${ }^{17}$ Furthermore, our results confirm that the resource curse hypothesis is valid in the GCC countries in the long run. This finding opens up the debate on the importance of diversifying the GCC economies.

${ }^{17}$ For more details, see Al-Saidi and Haghirian (2020). 


\section{References}

Abdel Gelil I (2017) Environmental policy framework. Saab, N., (Ed.), Arab environment in 10 years. Annual report of Arab forum for environment and development; Saab, N., (Ed.), pp. 31-62, Beirut, Lebanon. Technical Publications.

Abdulahi M E, Shu Y, Khan M A (2019) Resource rents, economic growth, and the role of institutional quality: a panel threshold analysis. Resour Policy 61: 293-303. https://doi.org/10.1016/j.resourpol.2019.02.011.

Adekoya O B (2020) Revisiting oil consumption-economic growth nexus: resource-curse and scarcity tales. Resour Policy. 101911 (forthcoming). https://doi.org/10.1016/j.resourpol.2020.101911.

Al-Saidi M, Haghirian M (2020) A quest for the Arabian atom? Geopolitics, security, and national identity in the nuclear energy programs in the Middle East. Energy Res Soc Sci 68: 101582 (forthcoming). https://doi.org/10.1016/j.erss.2020.101582.

AFED (2017) Arab environment in 10 years. Annual report of Arab forum for environment and development; Saab, N., (Ed.); Beirut, Lebanon. Technical Publications.

AFED (2009) Arab environment: climate change. Annual report of Arab forum for environment and development; Tolba, M. and Saab, N., (Ed.); Beirut, Lebanon. Technical Publications.

AFED (2008) Arab environment: future challenges. Annual report of Arab forum for environment and development; Tolba, M. and Saab, N., (Ed.); Beirut, Lebanon. Technical Publications.

AFED (2006) Arab public opinion \& the environment conference report of 18 country survey. Beirut, Lebanon, 16-17 June.

Al-Iriani, M A, Trabelsi M (2015) The economic impact of phasing out energy consumption subsidies in GCC countries. $J$ Econ Bus 87: 35-49. https://doi.org/10.1016/j.jeconbus.2016.04.004.

Al-Iriani M A (2006) Energy-GDP relationship revisited: an example from GCC countries using panel causality. Energy Policy 34(17): 3342-50. https://doi.org/10.1016/j.enpol.2005.07.005.

Alkhathlan K, Alam M, Javid M (2012) Carbon dioxide emissions, energy consumption and economic growth in Saudi Arabia: a multivariate cointegration analysis. British $\mathrm{Br} \mathrm{J}$ Econ Manage Trade 2(4):327-39.

Alkhathlan K, Javid M (2013) Energy consumption, carbon emissions and economic growth in Saudi Arabia: an aggregate and disaggregate analysis. Energy Policy 62:152532. https://doi.org/10.1016/j.enpol.2013.07.068. 
Al-Mulali U, Ozturk I (2015) The Effect of energy consumption. Urbanization, Trade Openness, Industrial Output, and the Political Stability on the Environmental Degradation in the MENA Region. Energy 84: 382-389. https://doi.org/10.1016/j.energy.2015.03.004.

Al-Sarihi A (2018) Prospects for climate change integration into the GCC economic diversification strategies. LSE Middle East Center. Paper series 20, February.

Baumgartner S, Quaa M (2010) What is sustainability economics? Ecol Econ 69:445-50. https://doi.org/10.1016/j.ecolecon.2009.11.019.

British Petroleum 2020. BP Statistical review of the world energy, edition 69.

Dell'Anno R (2020) Reconciling empirics on the political economy of the resource curse hypothesis. evidence from long-run relationships between resource dependence, democracy and economic growth in Iran. Resour Policy 68: 101807. https://doi.org/10.1016/j.resourpol.2020.101807.

Dietz T, Rosa E A, York R (2009) Efficient well-being: rethinking sustainability as the relationship between human well-being and environmental impacts. Hum Ecol Rev 16: 114-123.

Dietz T, Rosa E A, York R (2012). Environmentally efficient well-being: is there a Kuznets curve? Appl Geogr 32(1): 21-28. https://doi.org/10.1016/j.apgeog.2010.10.011.

Heesterman A R G (2020) Containing the risk of catastrophic climate change. Clean Techn Environ Policy 22: 1215-1227. https://doi.org/10.1007/s10098-020-01868-1.

IMF 2017. The economic outlook and policy challenges in the GCC countries. International Monetary Fund, Washington DC, December.

Jorgenson A K (2014) Economic development and the carbon intensity of human wellbeing. Natural Climate Change 4: 186-189. https://doi.org/10.1038/nclimate2110.

Jorgenson A K, Alekseyko A, Giedraitis V (2014). Energy consumption, human wellbeing and economic development in central and eastern European nations: a cautionary tale of sustainability. Energy Policy 66: 419-427. https://doi.org/10.1016/j.enpol.2013.11.020.

Kais S, Sami H (2016) An econometric study of the impact of economic growth and energy use on carbon emissions: Panel data evidence from fifty eight countries. Renew Sust Energy Rev 59: 1101-1110. https://doi.org/10.1016/j.rser.2016.01.054.

Knight K, Rosa E (2011) The environmental efficiency of well-being: a cross national analysis. Soc Sci Res 40(3): 931-949. https://doi.org/10.1016/j.ssresearch.2010.11.002.

Long X, Ji X (2019) Economic growth quality, environmental sustainability, and social welfare in China - provincial assessment based on genuine progress indicator (GPI). Ecol Econ 159: 157-176. https://doi.org/10.1016/j.ecolecon.2019.01.002.

Mankiw, N. G., D. Romer, and D. N. Weil. 1992. "A Contribution to the Empirics of Economic Growth.” Quarterly Journal of Economics 107: 407-437.

Mahmood H, Alkhateeb T T Y, Furgan M (2020) Industrialization, urbanization and CO2 emissions in Saudi Arabia: Asymmetry analysis. Energy Rep 6: 1553-1560. https://doi.org/10.1016/j.egyr.2020.06.004. 
Mehrara M (2007) Energy consumption and economic growth: the case of oil exporting countries. Energy Policy 35(5): 2939-2945. https://doi.org/10.1016/j.enpol.2006.10.018.

Ozcan B (2013) The nexus between carbon emissions, energy consumption and economic growth in Middle East countries: a panel data analysis. Energy Policy 62:1138-47. https://doi.org/10.1016/j.enpol.2013.07.016.

Pesaran M H, Shin Y, Smith R P (1999) Pooled mean group estimation of dynamic heterogeneous panels. $J$ Am Stat Assoc 94(446): 621-634. https://www.jstor.org/stable/2670182.

Pedroni P (1999) Critical values for cointegration tests in heterogeneous panels with multiple regressors. Oxford $B$ of Econ Stat 61(S1): 653-670. https://doi.org/10.1111/1468-0084.0610s1653.

Pedroni P (2004) Panel cointegration: asymptotic and finite sample properties of pooled time series tests with an application to the PPP hypothesis. Economet Theor 20(3): 597625. https://doi.org/10.1017/S0266466604203073.

Romer P M (1990) Endogenous technological change. J Polit Econ 98(5): 71-102. https://www.jstor.org/stable/2937632.

Sabapathy J (2007) Sustainable consumption and production. Cambridge Programme for Industry. Cambridge University, London.

Salahuddin M, Gow J (2014) Economic growth, energy consumption and CO2 emissions in Gulf Cooperation Council countries. Energy 73:44-58. https://doi.org/10.1016/j.energy.2014.05.054.

Sbia R, Shahbaz M, Ozturk I (2017) Economic growth, financial development, urbanisation and electricity consumption nexus in UAE. Econ Res-Ekon Istraz 30(1): 527-549. https://doi.org/10.1080/1331677X.2017.1305792.

Sbia R, Shahbaz M, Hamdi H (2014) A contribution of foreign direct investment, clean energy, trade openness, carbon emissions and economic growth to energy demand in UAE. Econ Model 36:191-197. https://doi.org/10.1016/j.econmod.2013.09.047.

Sethi P, Chakrabarti D, Bhattacharjee S (2020) Globalization, financial development and economic growth: perils on the environmental sustainability of an emerging economy. $J$ Policy Model 42: 520-535. https://doi.org/10.1016/j.jpolmod.2020.01.007.

Shahbaz M, Sbia R, Hamdi H, Ozturk I. (2014) Economic growth, electricity consumption, urbanization and environmental degradation relationship in United Arab Emirates. Ecolo Indic 2014; 45: 622-631. https://doi.org/10.1016/j.ecolind.2014.05.022.

Squalli J (2007) Electricity consumption and economic growth: bounds and causality analyses of OPEC countries. Energ Econ 29(6):1192-205. https://doi.org/10.1016/j.eneco.2006.10.001.

Sweidan O D (2018) Economic performance and carbon intensity of human well-being: empirical evidence from the MENA region. J Environ Plann Man 61(4): 699-723. https://doi.org/10.1080/09640568.2017.1332986. 
Sweidan O D, Alwaked A A (2016) Economic development and the energy intensity of human well-being: evidence from the GCC countries. Renew Sust Energ Rev 55:13631369. https://doi.org/10.1016/j.rser.2015.06.001.

Sweidan O D (2012) Energy Consumption and Real Output: Evidence from the UAE Economy. OPEC Energ Rev 36(3): 287-300. http://dx.doi.org/10.1111/j.17530237.2012.00213.x.

The New Economics Foundation 2009. The happy planet index. London, the UK.

Tiba S, Omri A (2017) Literature survey on the relationships between energy, environment and economic growth. Renewable and Sustainable Energy Reviews 69:1129-1146. Renew Sust Energ Rev 69: 1129-1146. https://doi.org/10.1016/j.rser.2016.09.113.

Westerlund J. (2005) New simple tests for panel cointegration. Economet Rev 24(3): 297-316. https://doi.org/10.1080/07474930500243019. 
Figures

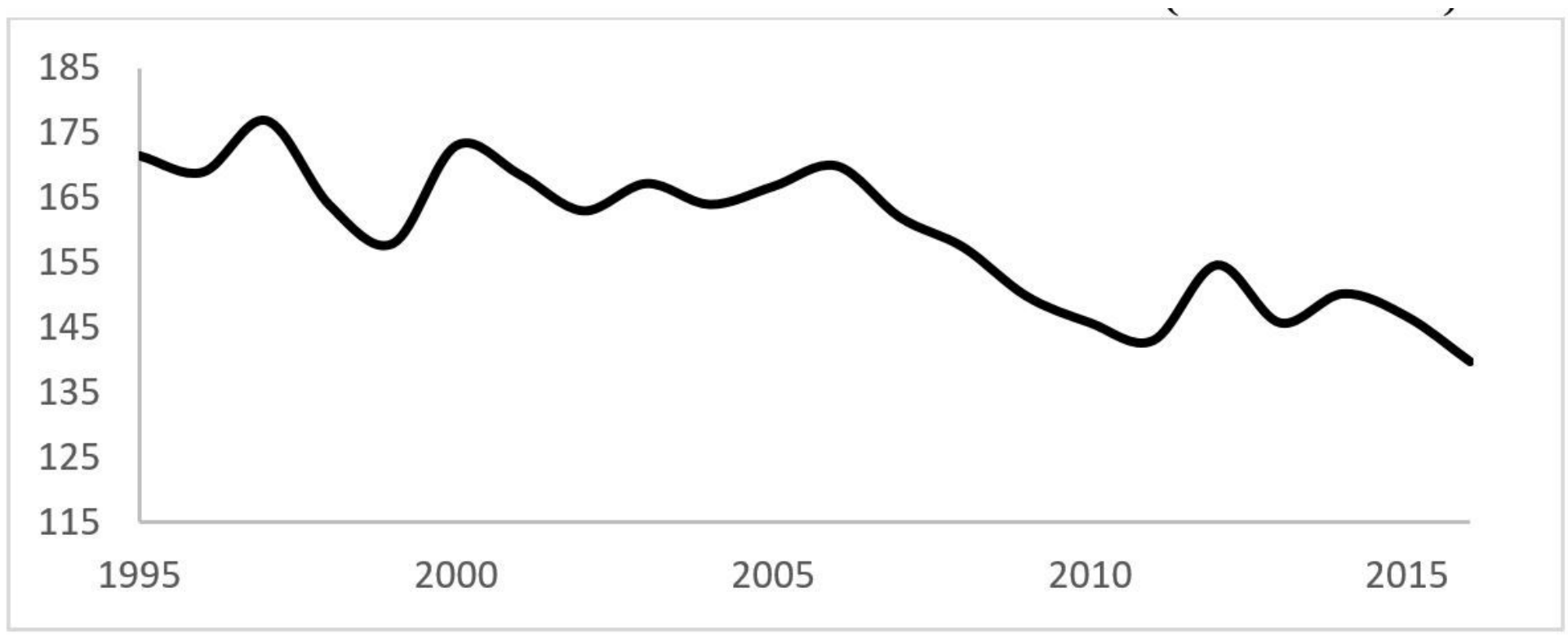

Figure 1

The CO2 emission per capita of the GCC countries during the period (1995-2016)(metric tons) Source: The World Bank Development Indicators.

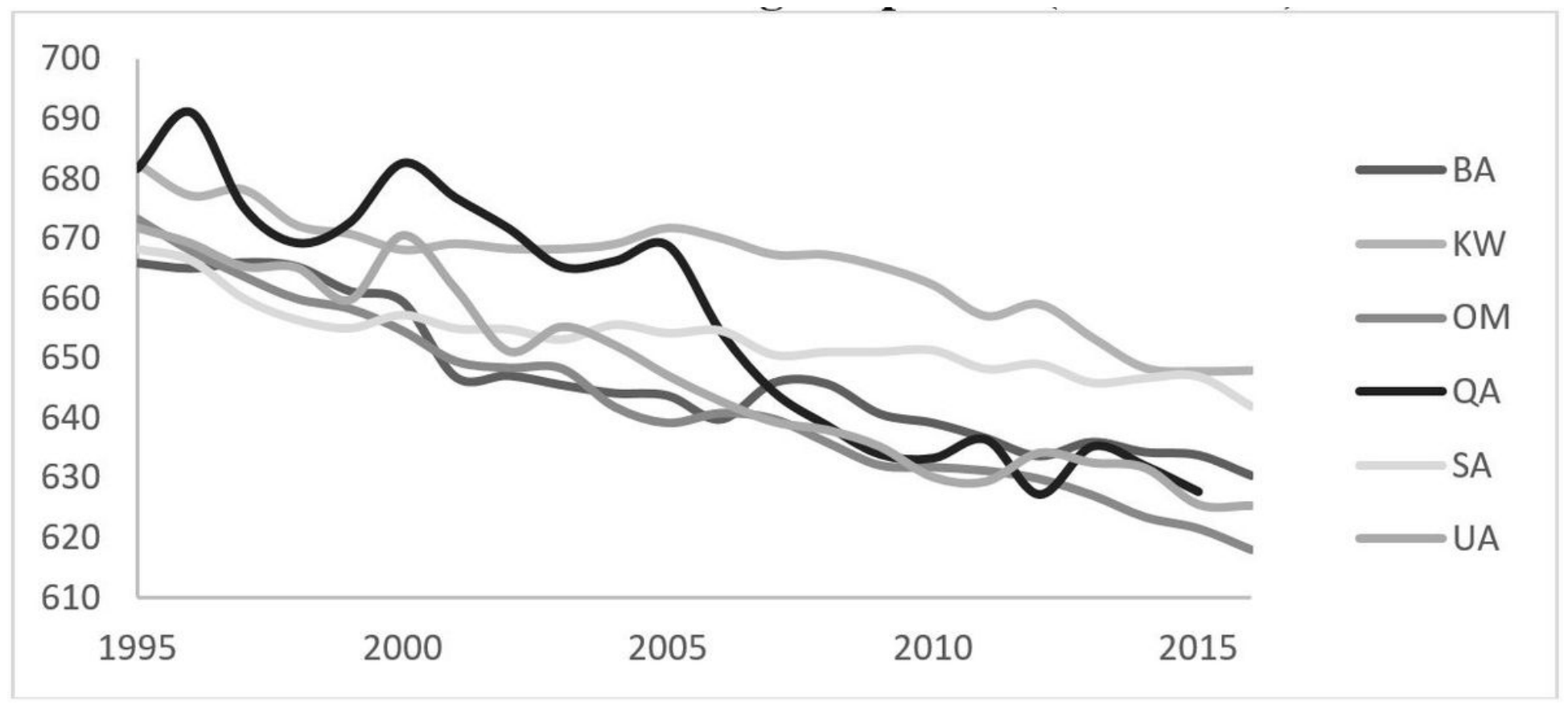

Figure 2

The environmental stress, LnSit, of the GCC countries during the period (1995-2016) Source: computed by the authors. 


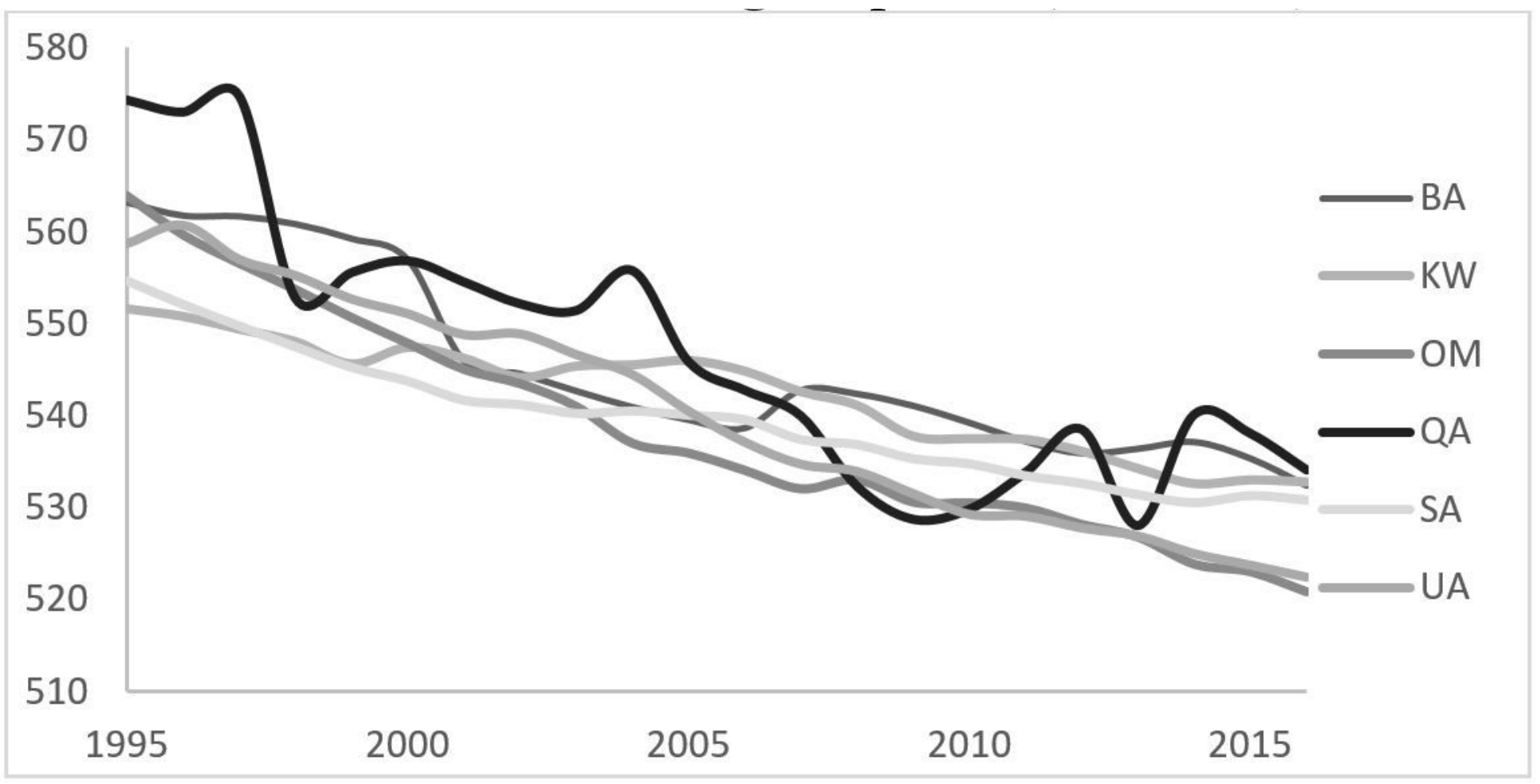

Figure 3

The environmental stress indicator, LnSGit, of the GCC countries during the period (1995-2016) Source: computed by the authors.

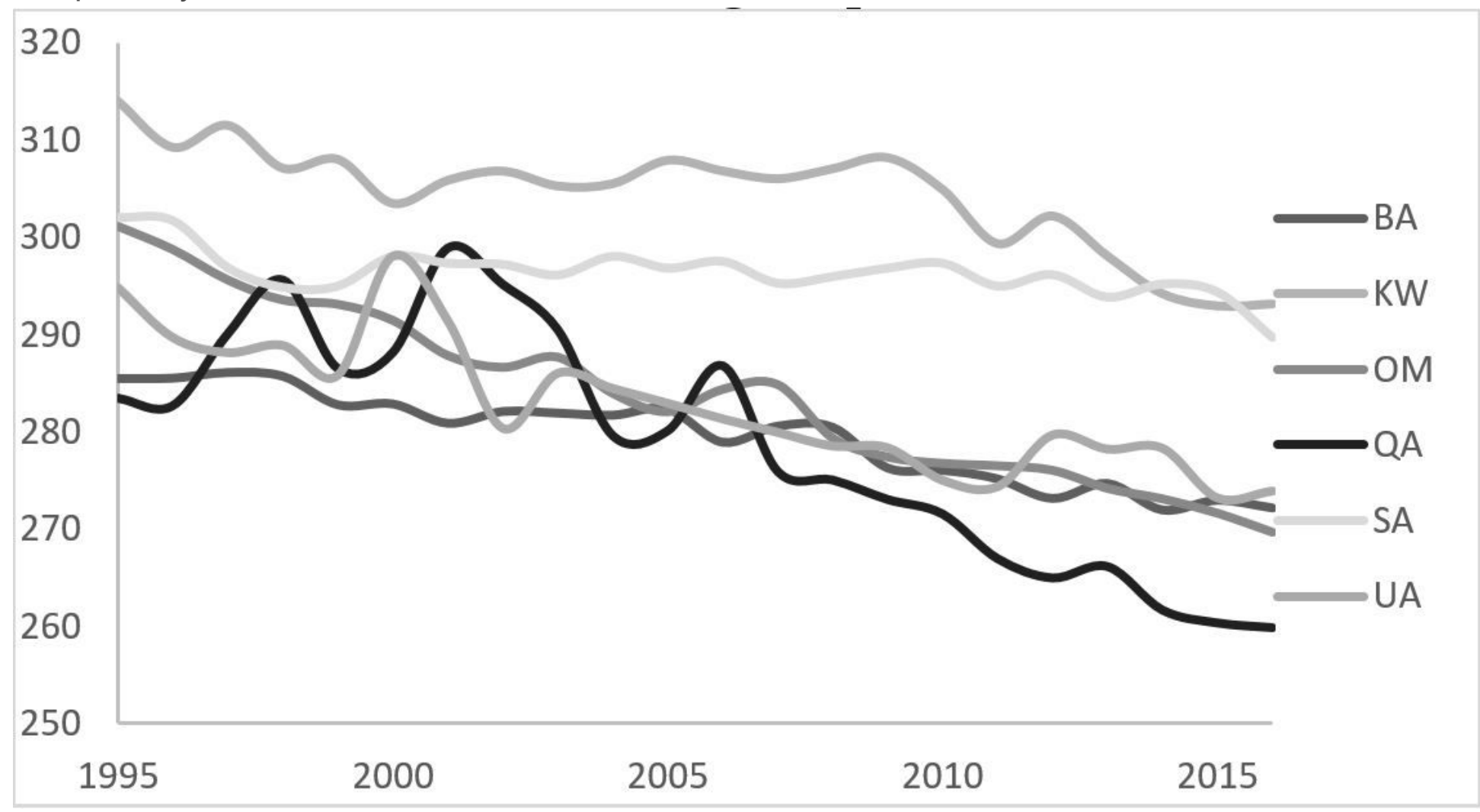

Figure 4 
The environmental stress indicator, LnSPit, of the GCC countries during the period (1995-2016). Source: computed by the authors. 